\title{
Impact of Management on the Physical Attributes of a Dystrophic Yellow Latosol
}

\author{
Maryzélia Furtado de Farias ${ }^{1}$, Carlos Eduardo Linhares Feitosa ${ }^{2}$, Khalil de Menezes Rodrigues ${ }^{1}$, \\ Liliane Carvalho Teixeira ${ }^{1}$, Mariléia Barros Furtado ${ }^{1} \&$ Luisa Julieth Parra-Serrano ${ }^{1}$ \\ ${ }^{1}$ Federal University of Maranhão (UFMA), Brazil \\ ${ }^{2}$ Federal University of Ceará (UFC), Brazil \\ Correspondence: Maryzélia Furtado de Farias, Federal University of Maranhão, CCAA-UFMA, MA-230, km 04, \\ s/n, Boa Vista, 65500-000, Chapadinha, MA, Brazil. Tel: 55-98-3471201. E-mail: maryzelia@ig.com.br
}

Received: February 2, $2017 \quad$ Accepted: March 23, $2017 \quad$ Online Published: April 15, 2017

doi:10.5539/jas.v9n5p217 URL: https://doi.org/10.5539/jas.v9n5p217

The research is financed by FAPEMA.

\begin{abstract}
Soil use and management systems aim to create conditions that are favorable to crop growth. The hypothesis is that areas subject to intensive use of agricultural machinery and animal trampling tend to have a soil structure that is altered by aggregate fragmentation, which causes soil compaction and consequently decreases the soil's physical and hydraulic properties. The aim of this study was to assess and compare the physical and hydraulic parameters of a dystrophic yellow latosol in an area of Cerrado in the municipality of Chapadinha, Maranhão, Brazil under different use and management systems. The following five use and management systems were studied with five replicates: native forest (control), slash-and-burn agriculture, grassland, no-till crop production and conventional tillage. Data analysis was performed using a completely randomized experimental design. The soil's density, macroporosity, microporosity, total porosity, hydraulic conductivity, infiltration, water retention curve, penetration resistance and Soil quality assessment index ( $\mathrm{S}$ index) were assessed for all management systems. The soil use and management systems were found to have a significant effect on the penetration resistance and the water infiltration rate. The native forest and slash-and-burn agriculture areas provided the highest soil water infiltration rates and the lowest soil penetration resistance. A multivariate analysis identified the variables associated with each soil use and management system. The slash-and-burn agriculture area had the highest $\mathrm{S}$ index, which means it provided soil of the best physical quality.
\end{abstract}

Keywords: Guelph permeameter, $\mathrm{S}$ index, soil porosity

\section{Introduction}

Representing the water retention and penetration resistance of a soil mathematically is necessary for studies of the physical and structural quality of the soil and the growth and development of plant roots (Silva et al., 2008). Rossetti et al. (2012) report that using agricultural implements in places without or with low vegetation cover directly impacts the soil's physical attributes by decreasing its porosity. In turn, these structural changes promote changes in the soil's physical attributes, including its porosity, density and resistance to root penetration (Silva et al., 2014).

The infiltration capacity is one of the main characteristics of a soil because it reflects the maximum capacity of the soil to allow water entry under certain conditions, which makes it one of the most important parameters affecting irrigation. A soil's infiltration capacity significantly affects all phases of irrigation and therefore the system's performance (Cunha et al., 2009).

Several field methods have been used to determine the water infiltration rate of a soil; these include the ring infiltrometer method, which stands out because it is simple and easy to perform (Santos et al., 2013a). The hydraulic conductivity is one of the soil properties that best highlight the structural differences between the various layers of the soil profile (Rossetti \& Centurion, 2013). 
Specific soil management practices may result in medium- and long-term degradation of agricultural systems, and soil compaction is one of the leading problems various regions currently face (Oliveira et al., 2014). Soil compaction is characterized by changes in the physical properties of a soil due to a specific management practice in which the soil is subjected to a specific pressure, which reduces the soil's volume and increases its penetration resistance and density (Oliveira et al., 2010; Ohland et al., 2014).

The various soil use and management systems aim to create conditions that favor crop growth. However, the intensive use of agricultural machinery and animal trampling in pastures, particularly in the Cerrado region, which has little rainfall and inadequate soil moisture, may increase soil compaction and therefore decrease the infiltration rate.

The hypothesis is that in areas subjected to intensive use of agricultural machinery and animal trampling, the soil structure tends to be altered due to aggregate fragmentation, which compacts the soil and thereby reduces its physical and hydraulic attributes. The aim of this study was to assess and compare the physical and hydraulic parameters of a dystrophic yellow latosol located in the Cerrado area in eastern Maranhão, Brazil under different use and management systems.

\section{Materials and Methods}

The study was conducted in the municipality of Chapadinha in the eastern mesoregion of Maranhão state, at latitude $03^{\circ} 44^{\prime} 27^{\prime \prime} \mathrm{S}$ and longitude $43^{\circ} 18^{\prime} 44^{\prime \prime} \mathrm{W}$, from September, 2013, to August, 2014. The region has a hot and semi-humid equatorial climate with a mean precipitation of $2100 \mathrm{~mm}_{\text {year }}{ }^{-1}$ and two well-defined seasons, a rainy season that extends from January to June and a dry season with a water deficit from July to December (de Moura-Silva et al., 2016).

The predominant soil of the region is classified as a dystrophic yellow latosol (Santos et al., 2013b). To best understand the chemical and physical characteristics, soil samples were collected from 0 to $10 \mathrm{~cm}$ depths for fertility and grain size analysis using the method described in EMBRAPA (1997); the following results were obtained (Table 1).

Table 1. Collection of five samples for the acquisition of mean $\mathrm{pH}$, organic matter (OM) content, phosphorus (P) content, potassium (K) content, base sum (BS), cation exchange capacity (CEC), base saturation (V\%) and grain size, among other parameters of soils subjected to different management systems

\begin{tabular}{llllllllllll}
\hline Area & $\mathrm{pH}$ & $\mathrm{OM}$ & $\mathrm{P}$ & $\mathrm{K}$ & $\mathrm{BS}$ & $\mathrm{CEC}$ & $\mathrm{H}+\mathrm{Al}$ & $\mathrm{V}$ & Sand & Silt & Clay \\
\hline & & $\mathrm{g} \mathrm{dm}^{-3}$ & $\mathrm{mg} \mathrm{dm}^{-3}$ & ----------- & $\mathrm{mmol} / \mathrm{cm}^{3}$ & ----------- & $\%$ & $------------\mathrm{g} \mathrm{kg}^{-1}$---------- \\
$\mathrm{NF}$ & 4.1 & 21 & 8 & 2.3 & 18.3 & 51.3 & 33 & 36 & 810 & 70 & 120 \\
$\mathrm{CT}$ & 4.8 & 19 & 54 & 2.1 & 24.1 & 57.1 & 33 & 42 & 800 & 80 & 120 \\
$\mathrm{NT}$ & 4.7 & 20 & 4 & 3.1 & 28.1 & 56.1 & 28 & 50 & 860 & 20 & 120 \\
$\mathrm{SB}$ & 4 & 25 & 4 & 1.7 & 21.7 & 88.7 & 67 & 24 & 610 & 210 & 180 \\
$\mathrm{GL}$ & 4 & 38 & 3 & 6.5 & 22.5 & 122.5 & 100 & 18 & 600 & 160 & 240 \\
\hline
\end{tabular}

Note. NF: Native forest; CT: Conventional tillage; NT: No-till planting; SB: Slash-and-burn agriculture; GL: Grassland.

Soil samples were taken from each treatment, sampling sites were positioned randomly in the five treatment areas, however, near the collection sites of the other attributes: a) conventional tillage (CT: area planted with soybeans (Glycine max)); b) grassland (GL: elephant grass (Pennisetum purpureum) rotational grazing areas with about 15 units animals per hectare, with burning); c) slash-and-burn agriculture (SB: newly deforested area with only one year of burning before planting, cultivated with cassava (Manihot esculenta)); d) no-till crop production (NT: area planted with soybeans grown on pearl millet (Pennisetum glaucum) straw); and e) nature reserve with native forest (NF). A completely randomized experimental design was used in the data analysis. The plots were subdivided in time based on the infiltration rate data collected using a ring infiltrometer.

Samples were collected to characterize the soil grain size and fertility at depths from 0 to $10 \mathrm{~cm}$. The following physical and hydraulic variables were assessed using the method of EMBRAPA (1997): density, total porosity, macroporosity and microporosity. Undisturbed samples were collected in metal rings averaging $0.052 \mathrm{~m}$ in height and $0.04 \mathrm{~m}$ in diameter. The total porosity was determined using the indirect method. 
The soil water retention curve was obtained using the method of EMBRAPA (1997); disturbed samples were saturated for $24 \mathrm{~h}$, and a Richards extractor was used to determine the gravimetric moisture at each tension adjustment. Subsequently, the experimental points, based on the volumetric moisture, were fitted using the model proposed by Van Genuchten (1980) (Equation 1) and the software package Soil Water Retention Curve (SWRC) version 3.0 (Dourado Neto et al., 2001), which was developed by the Luiz de Queiroz College of Agriculture (Escola Superior de Agricultura "Luiz de Queiroz" - ESALQ) to obtain the empirical fit parameters $(\alpha, \mathrm{n}$ and $\mathrm{m})$.

$$
\theta=\theta_{i}+\frac{\left(\theta_{i}-\theta_{r}\right)}{\left[1+\left(\alpha \cdot \psi_{m}\right)^{n}\right]^{m}}
$$

Where, $\theta=$ moisture content (soil water content per unit volume, $\mathrm{m}^{3} \cdot \mathrm{m}^{-3}$ ); $\theta_{r}=$ residual moisture (water content at a tension of $1,500 \mathrm{kPa}, \mathrm{m}^{3} \mathrm{~m}^{-3}$ ); $\theta_{s}=$ saturated moisture (water content under saturated conditions, $\mathrm{m}^{3} \cdot \mathrm{m}^{-3}$ ); $\Psi_{m}$ $=$ water matric potential $(\mathrm{kPa})$; and $\alpha, m$ and $n=$ empirical parameters of the equation.

The $\mathrm{S}$ index was estimated using the water retention curve; it is equal to the value at the inflection point. The index $\mathrm{S}$ represents the distribution of the most frequent pore size and makes possible the direct comparison of different soils and the effects of different management practices on the physical quality of the soil. This slope is obtained by fitting the curve to a mathematical model, and the parameters of this mathematical model are used to calculate the index using Equation (2), which was proposed by Dexter (2004):

$$
S=-n\left(\theta_{s}-\theta_{r}\right)\left[1+\frac{1}{m}\right]^{-(1+m)}
$$

Where, $S=$ slope of the water curve at its inflection point; $\theta_{r}=$ residual water content $\left(\mathrm{g} \mathrm{g}^{-1}\right) ; \theta_{s}=$ saturated water content $\left(\mathrm{g} \mathrm{g} \mathrm{g}^{-1}\right)$; and $m$ and $n=$ empirical parameters of the equation.

A ring infiltrometer and a Guelph permeameter were used to assess the soil's water infiltration rate. The Guelph Permeameter (GP) description of steady and constant head discharge of water from an uncased well into unsaturated soil is given by Reynolds (2008) and Reynolds et al. (1985). Five soil water infiltration tests were performed in each area using the double-ring method, in which concentric rings were fixed vertically to the soil. A 5-cm layer of water was maintained, and its infiltration was measured after 2, 5 and $10 \mathrm{~min}$. The soil's water permeability was determined using the Guelph permeameter and a 5-cm hydraulic load.

The field hydraulic conductivity $(K f s)$ was determined using the Guelph permeameter with a 5-cm hydraulic load following Reynolds, Elrick and Tan (1989; Equation 3).

$$
K f_{s}=\frac{C A R}{\left(2 \pi H^{2}+\pi a^{2} C+\frac{2 \pi H}{\alpha}\right)}
$$

Where, $H=$ applied hydraulic load $(\mathrm{cm}) ; a=$ diameter of the soil hole used in the measurement $(\mathrm{cm}) ; C=$ shape factor that depends on $\mathrm{H} / \mathrm{a}$ and the soil type (tabulated); $A$ = factor estimated by assessing the soil's macroporosity and texture; $R=$ difference in the permeameter reading of the water reservoir; and $\alpha=$ ratio between the soil's texture and structure $(\mathrm{cm})$.

Impact penetrometer tests were performed to a depth of $40 \mathrm{~cm}$ in the five areas using the method of Stolf (1991); they were subdivided into three test levels: 0-10, 10-20 and 20-40 cm. Soil samples were collected at depths from 0 to $10 \mathrm{~cm}$ to determine the gravimetric moisture as part of the evaluation of the soil's penetration resistance.

An analysis of variance was performed, and the assumptions of error homogeneity and heterogeneity were tested. The means were compared using the Tukey test at the 5\% significance level. ANOVA was performed using Assistant software (Silva \& Azevedo, 2006). A first-order linear principal component analysis (PCA) using an orthogonal linear transformation was performed to separate the correlated and uncorrelated variables by using a vector array to reduce the dimensionality (Silva Cruz et al., 2011) and facilitate interpretation of the dataset (Borůvka, Vacek, \& Jehlička, 2005) using Canoco ${ }^{\circledR}$, version 4.5. PCA is a type of indirect gradient analysis that assesses the data's total variability (Terbraak \& Smilauer, 2002). The biplot rule was used for the vector analysis (Kroonenberg, 2007). Principal components analysis used 5 samples of each treatment totaling 25 samples.

\section{Results and Discussion}

The soil's water retention differed between the soil use and management systems (Figure 1), which indicates that the soil's attributes affected its water content for the different potentials applied to the sample because soil 
horizons of the same texture class do not always have similar curves (Mota et al., 2008). Other factors, including rainfall intensity, soil sampling and wild animal traffic in the area, also affected the shapes of the curves.

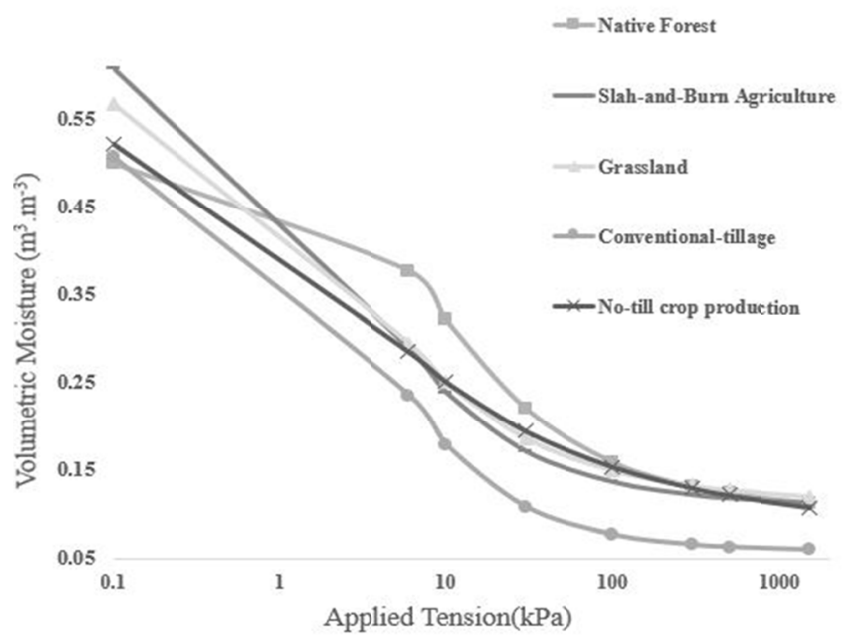

Figure 1. Water retention curves for the different soil use and management systems

At the saturation point, the slash-and-burn area had the highest soil moisture value, followed by the grassland area, the areas managed with other systems and, finally, the native forest area. However, for the other potentials applied, the reverse was observed in the water retention curves, with the native forest area retaining more water than all the others (Table 2). Water retention in a native forest is related to the increased number of micropores, whose size and geometry favor water retention by means of capillary action (Ramos et al., 2013). However, this was not observed under conventional tillage, which resulted in the lowest water retention, differing from the other soil use and management systems. This trend was maintained until the permanent wilt point because of the intensive use of agricultural machinery in the area. When production processes are introduced to latosols, the pores with the largest diameter may be severely affected by the first passes of agricultural machinery due to the high susceptibility of such soil to compaction (Carducci et al., 2011). Soil compression resulting from soil management increases the soil's matric potential due to the partial conversion of macropores into micropores and thereby reduces the macroporosity and increases the water retention (Oliveira et al., 2007).

When a ring infiltrometer was used, the highest infiltration rates occurred in the slash-and-burn agriculture and native forest areas because native forests have the most vegetation cover and are not subjected to mechanized processes. Conversely, slash-and-burn agriculture resulted in a higher infiltration rate and a higher hydraulic conductivity than the other soil use and management systems, which was probably due to the number of macropores and because this was the first year of slash-and-burn agriculture. However, the infiltration rates of the slash-and-burn agriculture and native forest areas did not differ significantly. The infiltration rate was higher at $2 \mathrm{~min}$ than at 5 and $10 \mathrm{~min}$, which is explained by the soil's initial water content.

The infiltration rate obtained with the Guelph permeameter and the hydraulic conductivity did not differ significantly among the soil use and management systems because of the wide range of data obtained under the different treatments. These results confirm the variability of the different soil use and management systems. Rossetti and Centurion (2013) found no differences in the hydraulic conductivity of soil subjected to conventional tillage and no-till crop production when assessing the physical and hydraulic traits of a red latosol.

The slash-and-burn agriculture and grassland areas showed increased hydraulic conductivity associated with increased macroporosity and total porosity, and no-till crop production and conventional tillage showed reduced hydraulic conductivity, which was saturated at a depth of $15 \mathrm{~cm}$ in almost all the soil use and management systems (Table 2). There was no variation in the soil's porosity composition in the slash-and-burn agricultural system, which indicates that ash has no significant effect on the pore volume; instead, it affects the pore quality, which changes the pore system's continuity.

The management systems did not cause significant alterations in most properties of the soil except in the macroporosity, due to its higher susceptible level. The hydraulic conductivity in the saturated condition is more 
dependent on the structure than on the soil texture, therefore its value increases when the degree of aggregation of the soil increases. The effect of the structure, especially the macropores (diameter greater than $50 \mu \mathrm{m}$ ), allows the clayey soil to exhibit values of hydraulic conductivity similar to those of the sandy soil (Gonçalves \& Libardi, 2013).

Table 2. Mean values of the soil density $\left(\mathrm{g} \mathrm{cm}^{-3}\right)$, infiltration rate (IR; $\left.\mathrm{cm} \mathrm{min}^{-1}\right)$, hydraulic conductivity $(\mathrm{K} ; \mathrm{cm}$ $\left.\mathrm{h}^{-1}\right)$, macroporosity (\%), microporosity (\%) and total porosity (\%) for the different soil use and management systems, Chapadinha - Maranhão, 2014

\begin{tabular}{|c|c|c|c|c|c|c|c|c|c|}
\hline Area & SD & IR (A2) & IR (A5) & IR (A10) & $\mathrm{IR}(\mathrm{P})$ & $\mathrm{K}$ & Macro & Micro & $\mathrm{TP}$ \\
\hline & $\mathrm{g} \mathrm{cm}^{-3}$ & \multicolumn{4}{|c|}{ 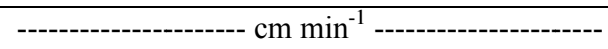 } & $\mathrm{cm} \mathrm{h}^{-1}$ & \multicolumn{3}{|c|}{---------------- \% --------------- } \\
\hline NF & $1.32 \mathrm{a}$ & $0.52 \mathrm{Aa}$ & $0.30 \mathrm{Ba}$ & $0.21 \mathrm{Ca}$ & $0.29 \mathrm{a}$ & $0.0091 \mathrm{a}$ & $44.5 \mathrm{bc}$ & $5.5 \mathrm{a}$ & $50.0 \mathrm{a}$ \\
\hline $\mathrm{CT}$ & $1.30 \mathrm{a}$ & $0.12 \mathrm{Ab}$ & $0.02 \mathrm{Bb}$ & $0.02 \mathrm{Bb}$ & $0.14 \mathrm{a}$ & $0.0059 \mathrm{a}$ & $42.7 \mathrm{c}$ & $7.3 \mathrm{a}$ & $50.0 \mathrm{a}$ \\
\hline NT & $1.24 \mathrm{a}$ & $0.21 \mathrm{Ab}$ & $0.10 \mathrm{Bb}$ & $0.09 \mathrm{Bab}$ & $0.25 \mathrm{a}$ & $0.0104 \mathrm{a}$ & $48.1 \mathrm{ab}$ & $4.8 \mathrm{a}$ & $53.0 \mathrm{a}$ \\
\hline GL & $1.12 \mathrm{a}$ & $0.14 \mathrm{Ab}$ & $0.06 \mathrm{Bb}$ & $0.04 \mathrm{Bb}$ & $0.31 \mathrm{a}$ & $0.0129 \mathrm{a}$ & $42.2 \mathrm{a}$ & $8.6 \mathrm{a}$ & $57.6 \mathrm{a}$ \\
\hline SB & $1.10 \mathrm{a}$ & $0.44 \mathrm{Aa}$ & $0.24 \mathrm{Ba}$ & $0.16 \mathrm{Ca}$ & $0.25 \mathrm{a}$ & $0.0105 \mathrm{a}$ & $35.0 \mathrm{a}$ & $6.6 \mathrm{a}$ & $58.4 \mathrm{a}$ \\
\hline $\mathrm{CV}(\%)$ & 18.46 & - & 36.73 & - & 87.98 & 89.46 & $5.30^{-1}$ & 37.52 & 17.49 \\
\hline $\mathrm{P}>\mathrm{F}^{2}$ & 0.3466 & - & 0.001 & - & 0.567 & 0.212 & 0.001 & 0.001 & 0.174 \\
\hline
\end{tabular}

Note. NF: Native forest; CT: Conventional tillage; NT: No-till crop production; GL: Grassland; SB: Slash-and-burn agriculture; SD = Soil density; IR (A2), IR (A5) and IR (A10) = Infiltration rate using a ring infiltrometer at 2, 5 and $10 \mathrm{~min}$, respectively; IR $(\mathrm{P})=$ Infiltration rate using a Guelph permeameter; TP = Total porosity; $\mathrm{CV}=$ Coefficient of variation. ${ }^{*}$ Means followed by the same uppercase (columns) or lowercase (rows) letters do not differ significantly according to the Tukey test at the $5 \%$ significance level.

Figure 2 shows that the highest penetration resistance was obtained in the grassland area due to the soil compaction caused by animal trampling; this is similar the findings of Senra et al. (2007), who determined that soil compaction was caused by animal trampling. This shows the deleterious effect of high animal units (AU) per area on soil surface sealing, which causes soil compaction, expressed by the penetration resistance, which reflects the intensity of the animal trampling in the field. The onset of soil surface sealing causes particle reorganization and densification and consolidation of the surface structure (Brandão et al., 2006). Even in thin layers, the effect of AU on the soil's physical and hydraulic properties primarily affects the water infiltration conditions, which corroborates the studies of Ludvíková et al. (2014), who measured increased penetration resistance for higher stocking rates, even in a short-term experiment.

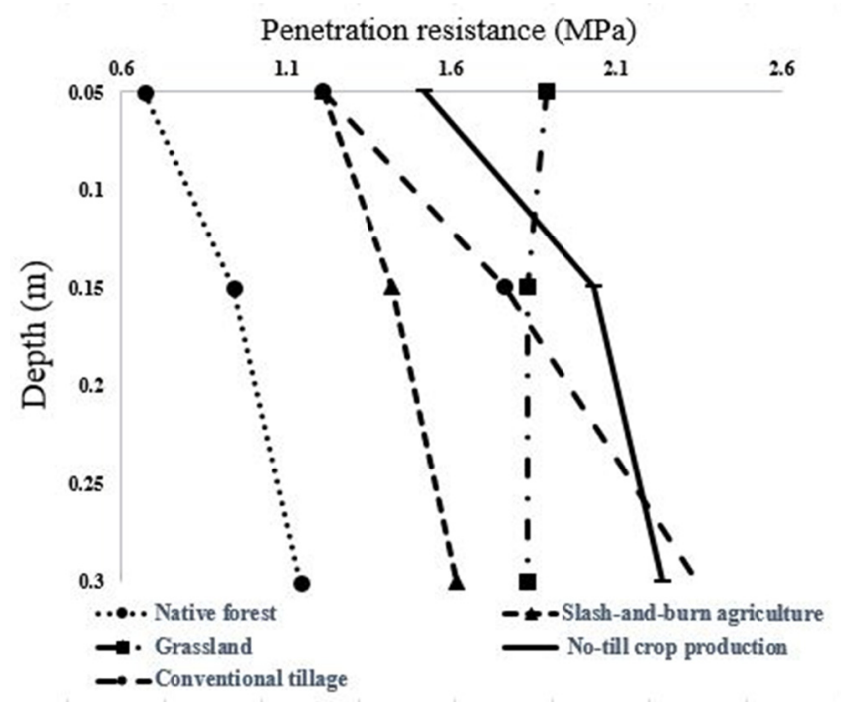

Figure 2. Penetration resistance of the soil at three depths under the different soil use and system 
The conventional tillage and no-till crop production areas showed an increase in the penetration resistance with depth at all depths and lower moisture than the areas under other soil use and management systems. The degree of soil compaction may be attributed to traffic in the form of heavy machinery, such as tractors and harvesters used for tilling, planting and harvesting (Costa \& Nishiyama, 2007). Decreased values were observed at depths between 0 and $10 \mathrm{~cm}$ under the conventional tillage system, evidencing the soil disaggregation caused by agricultural implements, which somewhat increases the total porosity of the profile and temporarily improves the root growth conditions.

In the $\mathrm{S}$ index analysis, the highest value was obtained for the slash-and-burn agriculture area, followed by the grassland, native forest, conventional tillage and no-till crop production areas (Table 3). The highest S index was observed for the system that used burning, slash-and-burn agriculture, which indicates that its use affected the soil's physical characteristics less. The $\mathrm{S}$ index of the grassland area most likely resulted from the high organic matter content of that area (Table1). Dexter (2004) and Streck et al. (2008) observed a close relationship between the $\mathrm{S}$ index and the soil's organic matter content. Differences in the structural quality index may also have resulted from the soil's organic matter content because the highest levels of organic matter in all the study areas were observed in the grassland, which may have contributed to improved pore system rearrangement and therefore improved physical conditions for plant growth.

The native forest area had a lower S index than the managed areas did. Ramos et al. (2013) obtained a lower S index for a native forest area than that for managed areas when studying red latosol. The conventional tillage and no-till crop production areas showed lower values of the $\mathrm{S}$ index than the other areas did, which may be attributable to machinery traffic and inadequate use of agricultural implements in friable soil, thus favoring compaction (Klein \& Libardi, 2002). The results showed that even under intensive management, these areas provide good physical conditions for plant growth with $\mathrm{S}$ indices that are greater than 0.056 .

Table 3. Mean $\mathrm{S}$ index for each soil management system used

\begin{tabular}{lll}
\hline Soil use & Texture class & S index \\
\hline Native forest & Loamy sand & -0.12228 \\
Conventional tillage & Sandy loam & -0.10093 \\
No-till crop production & Loamy sand & -0.06972 \\
Grassland & Sandy clayed loam & -0.15989 \\
Slash-and-burn agriculture & Sandy loam & -0.17325 \\
\hline
\end{tabular}

The principal component analysis is shown in Figure 3. The results show that axis I explains $58.8 \%$ of the data variability; it differentiates the soil use and management systems by separating the native forest and slash-and-burn agriculture areas, which are on the right-hand side, from the grassland, no-till crop production and conventional tillage areas, which are on the left-hand side. The first axis consists of variables that explain most of the data variation, and the second axis corresponds to the second highest amount of variation and is independent of the first axis (Roy Bhowmik \& Sen Roy, 2006). This result shows that the slash-and-burn agriculture area was similar to the native forest area because this was the first year this management system was used; however, slash-and-burn agriculture did differ from the other farming systems. Soil management systems that enable increased plant residue input and decreased soil use favor increases in the soil's organic carbon content and the amount of electric charge in the soil (Kuwano et al., 2014).

Of all the study variables, the soil's density and microporosity were the least able to explain the differences among the study areas because the vectors were closer to the origin. The soil densities obtained were inversely proportional to the hydraulic conductivity, the infiltration rate measured using the permeameter, the macroporosity and the gravimetric moisture. The other variables assessed had strong interactions with the different soil use and management systems, as shown by the longer vectors.

In the analysis of the main components, $76.2 \%$ of the variability of the data can be explained by the axes I and II. Axis I explained $58.8 \%$ and axis II, $17.4 \%$. Axis I differentiated the conventional tillage with higher soil resistance to native forest penetration, showing the highest values of infiltration rate measured with the concentric rings at 2, 5 and 10 minutes. Axis II differentiated the conventional tillage with the highest values of soil density, grassland and slash-and-burn agriculture. Delalibera et al. (2012) also succeeded in separating the management areas using multivariate statistical analysis in their assessment of chemical and physical attributes of soils. 


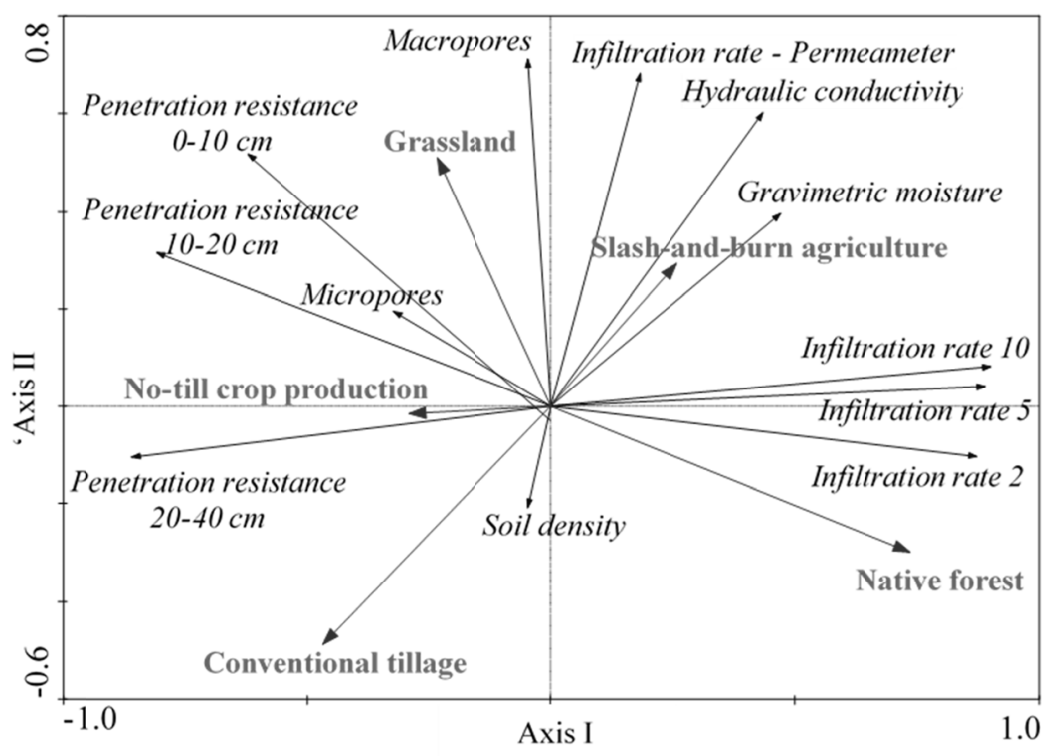

Figure 3. Center and standardized principal component analysis of the variables assessed for the different soil use and management systems

The highest penetration resistances were associated with the grassland, no-till crop production and conventional tillage areas, and the highest soil densities were associated with the conventional tillage and native forest areas, which is confirmed by the smaller angle between their vectors. A higher soil penetration resistance may limit root growth and therefore plant growth (Reichert et al., 2009).

\section{Conclusion}

Soil use and management systems have significant effects on the soil's resistance to water penetration and infiltration. The native forest and slash-and-burn areas had the highest water infiltration rates and the lowest penetration resistances. Additionally, the native forest area had the highest water retention capacity at field capacity, while the slash-and-burn agriculture was the soil use and management system with the highest $\mathrm{S}$ index, which indicates that it is the soil with best physical characteristics.

\section{References}

Borůvka, L., Vacek, O., \& Jehlička, J. (2005). Principal component analysis as a tool to indicate the origin of potentially toxic elements in soils. Geoderma, 128(3-4), 289-300. https://doi.org/10.1016/j.geoderma. 2005.04.010

Brandão, V. S., Cecilio, R. A., Pruski, F. F., \& Silva, D. D. (2006). Infiltração da água no solo (3th ed.). Viçosa: UFV.

Carducci, C. E., Oliveira, G. C. de, Severiano, E. da C., \& Zeviani, W. M. (2011). Modelagem da curva de retenção de água de Latossolos utilizando a Equação Duplo Van Genuchten. Revista Brasileira de Ciência do Solo, 35(1), 77-86.

Costa, P. M., \& Nishiyama, L. (2007). Utilização do permeâmetro guelph e penetrômetro de impacto em estudos de uso e ocupação dos solos em bacias hidrográficas. Caminhos de Geografia, 8(24), 131-143. Retrieved from http://www.seer.ufu.br/index.php/caminhosdegeografia/article/view/15589

Cunha, J. L. X. L., Albuquerque, A. W., Silva, C. A., Araújo, E., \& Santos Junior, R. B. (2009). Velocidade de infiltração da água em um latossolo amarelo submetido ao sistema de manejo plantio direto. Revista Caatinga, 22(1), 199-205. https://periodicos.ufersa.edu.br/revistas/index.php/sistema/article/view/960/548

de Moura-Silva, A. G., Aguiar, A. C. F., de Moura, E. G., \& Jorge, N. (2016). Influence of soil cover and N and $\mathrm{K}$ fertilization on the quality of biofortified QPM in the humid tropics. Journal of the Science of Food and Agriculture, 96, 3807-3812. https://dx.doi.org/10.1002/jsfa.7423 
Delalibera, H. C., Weirich Neto, P. H., \& Nagata, N. (2012). Management zones in agriculture acording to the soil and landscape variables. Engenharia Agrícola, 32(6), 1197-1204. https://dx.doi.org/10.1590/ S0100-69162012000600021

Dexter, A. R. (2004). Soil physical quality. Part I. Theory, effects of soil texture, density, and organic matter, and effects on root growth. Geoderma, 120(3-4), 201-214. https://doi.org/10.1016/j.geoderma.2003.09.004

Dourado Neto, D., Nielsen, D. R., Hopmans, J. W., Reichardt, K., Bacchi, O. O. S., \& Lopes, P. P. (2001). Programa para confecção da curva de retenção de água no solo, modelo Van Genuchten. Soil Water Retention Curve, SWRC (Version 3.00 beta). Piracicaba, Universidade de São Paulo.

Empresa Brasileira de Pesquisa Agropecuária (EMBRAPA). (1997). Manual de métodos de análises do solo. (2nd ed.). Rio de Janeiro: Ministério da Agricultura e do Abastecimento.

Gonçalves, A. D. M. A., \& Libardi, P. L. (2013). Análise da determinação da condutividade hidráulica do solo pelo método do perfil instantâneo. Revista Brasileira de Ciência do Solo, 37, 1174-1184. https://dx.doi.org/10.1590/S0100-06832013000500007

Klein, V. A., \& Libardi, P. L. (2002). Densidade e distribuição do diâmetro dos poros de um Latossolo Vermelho sob diferentes sistemas de uso e manejo. Revista Brasileira de Ciência do Solo, 26(4), 857-867. https://dx.doi.org/10.1590/S0100-06832002000400003

Kroonenberg, P. M. (1995). Introduction to biplots for GxE tables. Research Report \#51 (pp. 1-22). Brisbane, Austrália: The University of Queensland.

Kuwano, B. H., Knob, A. F., Dáfila, S. L., Melém Júnior, N. J., Godoy, L., Diehl, R. C., ... Nogueira, M. A. (2014). Soil quality indicators in a rhodic kandiudult under different uses in northern Parana, Brazil. Revista Brasileira de Ciência do Solo, Viçosa, 38(1), 50-59. https://dx.doi.org/10.1590/S0100-06832014000100005

Ludvíková, V., Pavlů, V. V., Gaisler, J., Hejcman, M., \& Pavlů, L. (2014). Long term defoliation by cattle grazing with and without trampling differently affects soil penetration resistance and plant species composition in Agrostis capillaris grassland. Agriculture, Ecosystems \& Environment, 197(1), 204-211. https://doi.org/ 10.1016/j.agee.2014.07.017

Mota, J. C. A., Assis Junior, R. N. de, Amaro Filho, J., \& Libardi, P. L. (2008). Algumas propriedades físicas e hídricas de três solos na Chapada do Apodi, RN, cultivados com melão. Revista Brasileira de Ciências do Solo, 32(1), 49-58. https://dx.doi.org/10.1590/S0100-06832008000100006

Ohland, T., Lana, M. do C., Frandoloso, F., Rampim, L., Bergmann, J. R., \& Cabreira, D. T. (2014). Influência da densidade do solo no desenvolvimento inicial do pinhão-manso cultivado em Latossolo Vermelho eutroférrico. Revista Ceres, 61(5), 622-630. https://doi.org/10.1590/0034-737X201461050004

Oliveira, A. P. P. de., Lima, E., Anjos, L. H. C. dos, Zonta, E., \& Pereira, M. G. (2014). Sistemas de colheita da cana de-açúcar: Conhecimento atual sobre modificações em atributos de solos de tabuleiro. Revista Brasileira de Engenharia Agrícola e Ambiental, 18(9), 939-947. https://doi.org/10.1590/1807-1929/ agriambi.v18n09p939-947

Oliveira, G. C., Severiano, E. C., \& Mello, C. R. (2007). Dinâmica da resistência à penetração de um Latossolo Vermelho da microrregião de Goiânia, GO. Revista Brasileira de Engenharia Agrícola e Ambiental, 11(3), 265-270. https://doi.org/10.1590/S1415-43662007000300004

Oliveira, V. S., Rolim, M. M., Vasconselos, R. F. B., Costa, Y. D. J., \& Edrosa, E. M. R. (2010). Compactação de um Argissolo Amarelo distrocoeso submetido a diferentes manejos. Revista Brasileira de Engenharia Agrícola e Ambiental, 14(7), 914-920. https://doi.org/10.1590/S1415-43662010000900002

Ramos, B. Z., Pais, P. S.A. M., Freitas, W. A., \& Junior, M. de S. D. (2013). Avaliação dos atributos physical and hydraulic em um LatossoloVermelho distroférrico sob diferentes sistemas de manejo-Lavras/Minas Gerais/Brasil. Revista de Ciências Agrárias, 36(3), 440-446.

Reichert, J. M., Suzuki, L. E. A. S., Reinert, D. J., Horn, R., \& Hakansson, I. (2009). Reference bulk density and critical degree-of-compactness for no-till crop production in subtropical highly weathered soils. Soil and Tillage Research, 102(2), 242-254. https://doi.org/10.1016/j.still.2008.07.002

Reynolds, W. D. (2008). Saturated hydraulic properties: Well permeameter. Soil sampling and methods of analysis (2nd ed., pp. 1025-1042). CRC Press, Boca Raton, FL.

Reynolds, W. D., Elrick, D. E., \& Clothier, B. E. (1985). The constant head well permeameter: Effect of unsaturated flow. Soil Science, 139(2), 172-180. https://doi.org/10.1097/00010694-198502000-00011 
Reynolds, W. D., Elrick, D. E., \& Tan, K. A. (1989). Hydraulic conductivity measurement in the unsaturated zone using improved well analyses. Ground Water Monitoring Review, 9(3), 184-193. https://doi.org/10.1111/j.1745-6592.1989.tb01162.x

Rossetti, K. V., \& Centurion, J. F. (2013). Sistemas de manejo e atributos physical and hydraulic de um latossolo vermelho cultivado com milho. Revista Brasileira de Engenharia Agrícola e Ambiental, 17(5), 472-479. https://doi.org/10.1590/S1415-43662013000500002

Rossetti, K. V., Andrioli, I., Centurion, J. F., Matias, S. S. R., \& Nóbrega, J. (2012). Atributos físicos do solo em diferentes condições de cobertura vegetal em área de plantio direto. Revista Brasileira de Ciências Agrárias, 7(3), 426-432. https://doi.org/10.5039/agraria.v7i3a1681

Roy Bhowmik, S. K., \& Sen Roy, S. (2006). Principal Component Analysis to study spatial variability of errors in the insat derived quantitative precipitation estimates over Indian monsoon region. Atmósfera, 19(4), 255-265. Retrieved from http://132.248.8.98:11802/atm/index.php/atm/article/view/8563

Santos, C. S. dos, Silva, P. D. da., Santos, D. P. dos S., Santos, J. C. C., \& Dos Santos, M. A. L. dos. (2013a). Avaliação da infiltração de água no solo pelo método de infiltrômetro de anel no agreste alagoano. Revista Verde, 8(2), 161-165. Retrieved from http://revista.gvaa.com.br

Santos, H. G. dos, Jacomine, P. K. T., Anjos, L. H. C. dos, Oliveira, V. A. de, Lumbreras, J. F., Coelho, M. R., ... Oliveira, J. B. de. (2013b). Sistema Brasileiro de Classificação de Solos (3th ed.). Brasília: Embrapa.

Selbach, J. F., \& Leite, J. R. S. A. (2008). Meio ambiente no Baixo Parnaíba: Olhos no mundo, pés na região. São Luis: EDUFMA.

Senra, A. F., Louzada, O. R., Vitorino, A. C. T., Souza, C. M. A., \& Mochi-Victor, D. (2007). Resistência à penetração em "Latossolo Vermelho" sob diferentes sistemas de uso e manejo do solo. Revista Ciências Técnicas Agropecuárias, 16(1), 31-36. Retrieved from http://www.redalyc.org/articulo.oa?id=93216108

Silva Cruz, J., De Assis Junior, R. N., Rocha Matias, S. S., \& Camacho Tamayo, J. H. (2011). Spatial variability of an Alfisol cultivated with sugarcane. Ciencia e Investigación Agraria, 38(1), 155-164. https://doi.org/10.4067/S0718-16202011000100015

Silva, Á. P. Da, Tormena, C. A., Fidalski, J., \& Imhoff, S. (2008). Funções de pedotransferência para as curvas de retenção de água e de resistência do solo à penetração. Revista Brasileira de Ciência do Solo, 32(1), 1-10. https://doi.org/10.1590/S0100-06832008000100001

Silva, F. A. S., \& Azevedo, C. A. V. (2006). A new version of the Assistant-statistical assistance software World Congress on Computers in Agriculture, 4. Proceedings, American Society of Agricultural and Biological Engineers, Orlando (pp. 393-396).

Silva, R. L., Matias, S. S. R., Lobat, M. G. R., \& Nóbrega, J. C. A. (2014). Atributos físicos do solo em diferentes coberturas vegetais na região sul do Piauí. Revista Caatinga, 27(3), 160-168. Retrieved from https://periodicos.ufersa.edu.br/index.php/sistema

Stolf, R. (1991). Teoria e teste experimental de fórmulas de transformação dos dados de penetrômetro de impacto em resistência do solo. Revista Brasileira de Ciência do Solo, 15, 229-235.

Streck, C. A., Reinert, D. J., Reichert, J. M., \& Horn, R. (2008). Relações do parâmetro S para algumas propriedades físicas de solos do sul do Brasil. Revista Brasileira de Ciência do Solo, 32, 2603-2612. https://doi.org/10.1590/S0100-06832008000700001

Terbraak, C. J. F., \& Smilauer, P. (2002). CANOCO Reference manual and CanoDraw for Windows user's guide: Software for Canonical Community Ordination (Version 4.5). Ithaca: Microcomputer Power.

Van Genuchten, M. T. (1980). A closed-form equation for predicting the hydraulic conductivity of unsaturated soils. Soil Science Society of America Journal, 44(5), 892-898. https://doi.org/10.2136/sssaj1980.0361599 $5004400050002 \mathrm{x}$

\section{Copyrights}

Copyright for this article is retained by the author(s), with first publication rights granted to the journal.

This is an open-access article distributed under the terms and conditions of the Creative Commons Attribution license (http://creativecommons.org/licenses/by/4.0/). 